\title{
Research on energy-saving strategies of college stadiums and sports venues under the concept of low carbon development
}

\author{
Yi Ke ${ }^{1, *}$ \\ ${ }^{1}$ School of Physical Education and Equestrian, Wuhan Business University, Wuhan, China
}

\begin{abstract}
More than half of the stadiums and sports venues in China are concentrated in the education system, and a large proportion of them are distributed in various colleges and universities across the country. Therefore, the planning, design, construction, operation and management of stadiums and sports venues of college and university are also getting more and more attention from the society and the educators. The author believes that under the concept of low carbon development, colleges and universities should focus on introducing ideas of energy conservation and put the concepts of low carbon economy development throughout the whole process and all aspects of operational management of stadiums and sports venues, so as to achieve the effects of sustainable development while fulfilling social responsibility of environmental protection, promoting green lifestyle among the students and contributing to green development model.
\end{abstract}

\section{INTRODUCTION}

After the Copenhagen Climate Conference, the term "low carbon" has become more and more well-known and understood. With the dramatic increase in population and uncontrolled production and lifestyle, carbon dioxide emissions are causing more and more serious climate problems, and the living environment and health security of human beings are under serious threat. As the second largest economy in the world, China is in a period of strategic opportunity for social and economic development, and the contradiction between economic development and environmental protection is more prominent, and with a large population and relatively poor resources, the crude economic model of high energy consumption and high pollution in the past years has caused great waste and affected the ecological balance. As an important initiative to cope with climate change, the concept of low carbon will continue to have a profound impact and change on the world. The whole society should recognize low-carbon, enter low-carbon, embrace low-carbon, let low-carbon gradually become the consensus of people, only in this way can we work together to truly develop a "low-carbon economy" based on low emissions, low pollution and low energy consumption, reduce the damage to the environment, and eventually change our lives implicitly, becoming a new normal in modern society.

According to the data of the Ministry of Education, by 2020 , there are 3005 higher education institutions in China, including 1272 undergraduate colleges and universities [1]. In the process of high-quality development of colleges and universities, the integration of sports and education has been elevated to a strategic height from the national level. With the rapid development of physical education in colleges and universities, the quantity, scale and quality of sports venues in colleges and universities have been steadily increasing, and the survey of the State General Administration of Sports shows that more than half of the sports venue area in China is concentrated in the education system [2]. College stadiums and sports venues are the hardware index to measure the soundness of college sports facilities, an important condition for the development of integration of sports and education, and also an important material carrier to reflect college campus sports culture. It is widely known that buildings consume more energy, both in construction and in the process of use. And college stadiums have the characteristics of large number and scales, therefore, the construction planning, design, operation and management of college stadiums are also getting more and more attention from the society and educators. Therefore, how to introduce the concept of green lowcarbon into the whole process of construction and use of college stadiums and sports venues will also be an important issue of the times.

\section{SIGNIFICANCE}

Convenient and excellent stadiums and sports venues can effectively guarantee the quality of physical education and stimulate students' love for sports, and also further promote the spread of campus sports culture. With the integration of sports and education, students in colleges and universities will be more and more motivated to participate in sports and the demand for sports venues will also increase.

In addition to the role of serving students, guaranteeing physical education and promoting the

Corresponding author: 623256467@qq.com 
development of campus sports, college stadiums also have a strong social service role and have a strong attraction to the masses around colleges and universities. Especially in the context of the implementation of the strategy of strengthening the country through sports, the enthusiasm of the people for physical exercise has also risen. Therefore, playing the role of university sports venues in social sports services can, on the one hand, promote the development of mass sports and improve the ability of university sports venues to serve the society, and on the other hand, improve the problem of insufficient supply of sports venues to a certain extent and ease the current situation of social sports venues.

More than half of the sports venues in China are concentrated in the education system, but the utilization efficiency of the sports venues in a considerable number of colleges and universities is low, and they are mainly used for teaching and training, and are not open to the society. There are various reasons for the waste of college stadium resources, but one of the important reasons is the consideration of colleges and universities for the operation cost after the opening of stadiums.

Therefore, the authors believe that under the concept of low carbon, colleges and universities should pay attention to the introduction of low-carbon ideas, put low-carbon, green and energy saving through the whole process and all aspects of the design, construction, operation and management of sports venues, more effectively play the efficacy and advantages of college sports venues, promote open operation, improve the utilization rate, save energy use to a greater extent, achieve the effect of environmental protection and lowcarbon at the same time, fulfil social responsibility and Promote the development of mass sports and the lifelong sports awareness of the masses.

\section{LOW-CARBON ENERGY-SAVING STRATEGIES FOR COLLEGE STADIUMS AND SPORTS VENUES}

\subsection{Integration of design with campus environment}

One is the better integration with the campus humanities and natural environment, through the design to achieve the harmony and unity of the stadium building and the campus environment, to avoid the incompatibility with the campus spirit, campus culture and campus natural landscape, that is, to avoid environmental damage, which is itself a kind of implementation of the concept of low carbon. Second, the effective integration with the campus functional layout, the design should not be isolated and simple, should meet the basic use function and design specifications, and the effective integration of the existing layout of campus functions, smoothly connect different functional layouts, and targeted amplification of the main functions. If the construction of the venue is mainly for teaching and training, it should be combined with the existing layout to consider the convenience of students entering the venue, and also consider the rationality of the teaching and training partition, and the mutual influence of other different buildings in the school to improve the compound, diversity and convenience.

\subsection{Targeted application of energy-saving and low-carbon materials and technologies}

At present, most colleges and universities in China have made plans to increase and expand sports venues, and most of them rely on state appropriation or school loans for college stadium construction. The single source of funds for college stadium construction leads to slow construction of college stadium sports facilities, while more than $80 \%$ of maintenance funds for college stadiums and sports venues rely on state appropriation [3]. In this situation, in the process of applying energysaving and low-carbon technologies to large stadiums, colleges and universities should be very cautious, the latest and most modern low-carbon energy-saving materials and technologies are not necessarily the best choice. Colleges and universities should even take the initiative to avoid using them, taking into account the construction and later use, maintenance capital pressure, and their non-profit public service nature, with economy, practicality and effectiveness as the basic principles, and more consideration from the stadium's own shape to optimize the design through more passive energy-saving technologies.

For example, the ventilation of college stadiums will be designed more reasonably, which can effectively reduce the installation scale of central air conditioning and the energy consumed, and reduce the load on the environment. This can really reduce the pressure of universities in the later stage, especially the financial pressure on the operation and maintenance of electrical facilities of stadiums, which is conducive to the psychological burden of universities to put down the operation cost and promote the further opening of stadiums, and achieve the purpose of energy saving and emission reduction and optimal use while improving the utilization rate.

Another example is that a reasonably designed transparent skylight in the gymnasium will make the power consumed by the lighting equipment significantly reduced when it is opened later. The gymnasium of China Agricultural University is a rectangle of $82.4 \mathrm{~m} \mathrm{x}$ $96 \mathrm{~m}$, and the roof is an anti-symmetrical folded surface, consisting of 12 bays of steel frame with a span of $82.4 \mathrm{~m}$ and a center distance of $8 \mathrm{~m}$, forming a high-low staggered shape. The stadium makes full use of the height difference of the roof shape features and "opens the skylight to the sun", forming an excellent natural lighting and ventilation effect. Generally, the pavilion is well-lit until 16:00 every day [4].

For the heat insulation and compartment design of college stadiums, we should also focus on the economic and stable perspective, and reasonably assemble some energy-saving and environment-friendly materials that have been verified by the market, reliable and cost- 
effective, so that the electric energy consumed by the stadium air conditioners can be significantly reduced.

\subsection{Focus on renovating existing stadiums and sports venues}

For some old stadiums that have been built for a long time, energy-saving renovation should be planned and demonstrated first, do not rush to start. The renovation of old stadiums and sports venues should be based on specific problems and combined with the actual situation. Only by grasping the key issues and promoting matters related to energy-saving renovation in a targeted manner can we achieve effective results.

For example, take the initiative to invite relevant experts and institutions to study and comprehensively analyze the energy consumption of old venues, find the main reasons for high energy consumption, and at the same time learn from the renovation experience of similar venues to develop targeted energy-saving renovation plans, so as to achieve the good expectation of immediate improvement. For some old venues with conditions, we can consider the installation and commissioning of intelligent systems and software to monitor the operating status of electrical equipment, optimize the operation of electrical equipment, and make intelligent adjustments without major renovation of existing structures and facilities, so that the waste of resources and damage to the environment can be reduced to a greater extent and the use of electrical energy can be saved [5].

\subsection{Strengthen the training and management of relevant personnel}

The managers of stadiums in colleges and universities are generally part-time teaching staff, and some are temporary external staff with non-professional management backgrounds, and generally lack of systematic and professional training, plus their own understanding of the concept of low carbon and energy saving is not deep enough, which to a certain extent also reduces the management and operation efficiency of stadiums and causes waste of resources. Therefore, it is necessary to continuously increase the education, publicity and training of stadium managers on low carbon, to raise their awareness of the importance of energy saving, to make energy saving penetrate into every detail of stadium management and become a routine. Energy saving should be incorporated into the daily management, and the management rules should be formulated, and the reward and punishment system should be implemented, and energy saving should be combined with the year-end work evaluation to promote energy saving by management [6].

\subsection{Develop standardized rules and regulations}

Colleges and universities should develop various systems and norms for energy saving and green operation of stadiums and sports venues. The better the system is, the more helpful it is for energy saving operation of stadiums. This requires not only the supervision and management of school leaders, but also the active cooperation and support of the stadium management team and all teachers and students of the school to keep the system and rules together.

\subsection{Promote the energy-saving utilization with green sharing strategy}

Since the 1990s, in order to promote the popularization of higher education, large scale university cities have been developed or built in various places, such as Haidian University City in Beijing, Xianlin University City in Nanjing and Hongshan University City in Wuhan. These university cities are mainly characterized by the close distance between schools, more frequent mutual exchanges and connections, and obvious aggregation effect.

Compared with the society, the sports resources of colleges and universities are more adequate, and the specifications and numbers of sports venues are also higher. For example, some universities have built natatoriums with high standard indoor heated swimming pools, and many social natatoriums are not comparable to their conditions.

Table 1. Research information of natatoriums in Hongshan University City in Wuhan

\begin{tabular}{|c|c|c|c|}
\hline Affiliation & $\begin{array}{l}\text { Swimming } \\
\text { pool }\end{array}$ & $\begin{array}{c}\text { Pool } \\
\text { specification }\end{array}$ & $\begin{array}{l}\text { Open } \\
\text { season }\end{array}$ \\
\hline $\begin{array}{l}\text { South Central } \\
\text { University for } \\
\text { Nationalities }\end{array}$ & $\begin{array}{c}10 \text { lane pool } \\
\text { with } \\
\text { constant } \\
\text { temperature }\end{array}$ & $\begin{array}{c}\text { Size: } \\
25 \mathrm{~m} * 50 \mathrm{~m} \\
\text { Depth: } 2.0 \mathrm{~m}\end{array}$ & $\begin{array}{l}\text { Summer, } \\
\text { Fall and } \\
\text { Winter }\end{array}$ \\
\hline $\begin{array}{c}\text { China } \\
\text { University of } \\
\text { Geosciences }\end{array}$ & $\begin{array}{l}10 \text { lane pool } \\
\text { with } \\
\text { constant } \\
\text { temperature }\end{array}$ & $\begin{array}{c}\text { Size: } \\
25 \mathrm{~m} * 50 \mathrm{~m} \\
\text { Depth: } 2.0 \mathrm{~m}\end{array}$ & $\begin{array}{l}\text { open } \\
\text { year- } \\
\text { round }\end{array}$ \\
\hline $\begin{array}{c}\text { Wuhan } \\
\text { University of } \\
\text { Technology }\end{array}$ & $\begin{array}{l}\text { A } 10 \text { lane } \\
\text { competition } \\
\text { pool and a } 4 \\
\text { lane training } \\
\text { pool with } \\
\text { constant } \\
\text { temperature }\end{array}$ & $\begin{array}{l}\text { Competition } \\
\text { pool size: } \\
25 \mathrm{~m} * 50 \mathrm{~m} \\
\text { Depth: } 2.0 \mathrm{~m} \\
\text { Training pool } \\
\text { size: } \\
10 \mathrm{~m} * 50 \mathrm{~m} \\
\text { Depth: } 1.8 \mathrm{~m} \\
\end{array}$ & $\begin{array}{l}\text { open } \\
\text { year- } \\
\text { round }\end{array}$ \\
\hline $\begin{array}{l}\text { Huazhong } \\
\text { Agricultural } \\
\text { University }\end{array}$ & $\begin{array}{c}8 \text { lane pool } \\
\text { with } \\
\text { constant } \\
\text { temperature }\end{array}$ & $\begin{array}{c}\text { Size: } \\
21 \mathrm{~m} * 50 \mathrm{~m} \\
\text { Depth: } 2.0 \mathrm{~m}\end{array}$ & $\begin{array}{l}\text { open } \\
\text { year- } \\
\text { round }\end{array}$ \\
\hline $\begin{array}{l}\text { Wuhan } \\
\text { Sports } \\
\text { University }\end{array}$ & $\begin{array}{c}\text { A } 8 \text { lane } \\
\text { competition } \\
\text { pool and a } \\
10 \text { lane } \\
\text { training pool } \\
\text { with } \\
\text { constant } \\
\text { temperature }\end{array}$ & $\begin{array}{c}\text { Competition } \\
\text { pool size: } \\
21 \mathrm{~m} * 50 \mathrm{~m} \\
\text { Depth: } 2.0 \mathrm{~m} \\
\text { Training pool } \\
\text { size: } \\
25 \mathrm{~m} * 25 \mathrm{~m} \\
\text { Depth: } 1.2 \mathrm{~m}\end{array}$ & $\begin{array}{l}\text { open } \\
\text { year- } \\
\text { round }\end{array}$ \\
\hline
\end{tabular}

However, since the opening of swimming pools involves a lot of running costs such as water and electricity, labor, disinfection and cleaning agents, lifesaving facilities and equipment, some colleges and 
universities do not make reasonable use of them, and there are even long-term idle situations.

In this case, the integration of shared stadium resources can kill two birds with one stone. In the case of colleges and universities with indoor heated swimming pools, for example, if we can open shared venues and courses to students of neighboring colleges and universities, we can strengthen the sports exchange among schools and solve the real problem faced by students of other colleges and universities who are interested in swimming but have no venues. Secondly, the cost of opening can be shared equally among colleges and universities, which greatly reduces the financial pressure of venue operation and greatly improves the utilization rate of college stadiums and sports venues, which is the best practice of low-carbon, energy-saving, green and sharing concept, and will also better lead college teachers and students to embrace green lifestyle in sports.

Table 2. Research information of universities with natatorium and its neighboring universities

\begin{tabular}{|c|c|}
\hline University & $\begin{array}{l}\text { Neighboring Universities } \\
\text { (Straight-line distance) }\end{array}$ \\
\hline $\begin{array}{l}\text { South Central } \\
\text { University for } \\
\text { Nationalities }\end{array}$ & $\begin{array}{c}\text { Zhongnan University of Economics } \\
\text { and Law }(0.2 \mathrm{~km}) \text {, Wuhan Textile } \\
\text { University }(0.4 \mathrm{~km}) \text {, Hubei Science and } \\
\text { Technology College }(1.1 \mathrm{~km}) \text {, Wuhan } \\
\text { Vocational and Technical College } \\
(1.3 \mathrm{~km})\end{array}$ \\
\hline $\begin{array}{l}\text { China University } \\
\text { of Geosciences }\end{array}$ & $\begin{array}{c}\text { Huazhong University of Science and } \\
\text { Technology }(0.5 \mathrm{~km}) \text {, Wuhan Institute } \\
\text { of Technology }(1.8 \mathrm{~km})\end{array}$ \\
\hline $\begin{array}{l}\text { Wuhan University } \\
\text { of Technology }\end{array}$ & $\begin{array}{c}\text { Wuhan University of Science and } \\
\text { Technology }(1.3 \mathrm{~km}) \text {, Hubei Water } \\
\text { Resources Technical College }(1.4 \mathrm{~km}) \text {, } \\
\text { Wuchang Shouyi University }(2.1 \mathrm{~km}) \text {, } \\
\text { Central China Normal University } \\
(2.2 \mathrm{~km})\end{array}$ \\
\hline $\begin{array}{l}\text { Huazhong } \\
\text { Agricultural } \\
\text { University }\end{array}$ & $\begin{array}{l}\text { Hubei Vocational College Of Bio- } \\
\text { Technology (1.7km), Zhongnan } \\
\text { University of Economics and Law } \\
\text { (1.6km), Hubei Vocational College of } \\
\text { Railway Transportation (1.9km) }\end{array}$ \\
\hline $\begin{array}{l}\text { Wuhan Sports } \\
\text { University }\end{array}$ & $\begin{array}{l}\text { Wuhan Electric Power Technical } \\
\text { College }(1.1 \mathrm{~km}), \text { Wuhan University } \\
(1.1 \mathrm{~km}), \text { Central China Normal } \\
\text { University }(1.2 \mathrm{~km}) \text {, Wuhan Social } \\
\text { Work Professional College }(1.3 \mathrm{~km})\end{array}$ \\
\hline
\end{tabular}

\section{Conclusion}

Leaders and managers of colleges and universities should be deeply aware of the importance of Low carbon economy development and Sustainable development. At the beginning of the planning project of stadiums and sports venues, they should plan in advance, organize sufficient demonstration and analysis, and scientifically and reasonably integrate green ecological and energysaving technology elements into the architectural design. Considering the limited financial resources of colleges and universities and the lack of professional managers, college stadiums should apply more passive energy- saving designs. Active energy saving technology is more advanced but more complicated. The reliability, stability and operational difficulty of the technology may also bring problems to the opening and operation of college stadiums later.

However, passive energy-saving design should also be adapted to local conditions and school-specific analysis. For example, if glass roof is used to transmit light on the roof of the stadium, the climate characteristics of the region to which the university belongs should be considered. If the university is located in southern China, with hot summers and warm winters and more rainfall, it is necessary to consider the increase in room temperature caused by solar radiation and the risk of roof leakage due to rainfall, and develop a targeted plan.

Colleges and universities should also fully consider the objective environment, characteristics, and reality around the venues and campuses in terms of energysaving renovation, operation and opening, and management and maintenance, and comprehensively use low-carbon energy-saving strategies to ensure the actual effect, while further improving the institutional mechanism and strengthening the training of management personnel.

Only by integrating the concept of green and lowcarbon development into the whole process and all links of college stadiums and implementing energy-saving strategies with high responsibility and rigorous spirit can we really transform the work efficiency into the kinetic energy of green development and finally make due contribution to Low carbon economy development and sustainable development.

\section{References}

1. https://www.yangtse.com/content/960174.html

2. https://www.sohu.com/a/452600818_583687

3. Xiena."On the enterprise management policy of college stadiums" Contemporary Economics .10 (2013): 42-43.

4. "The green concept of Olympic venues." China Construction.07(2008):14-19

5. "Highlighting the focus of energy conservation Strengthening energy-saving renovation Efforts to create a demonstration of energy conservation in sports venues." China Organ Logistics.08 (2016): 23

6. Bi Changquan, et al. "Research on energy-saving strategies for university libraries in the low-carbon era." Science and Technology Information .36 (2012): 34 